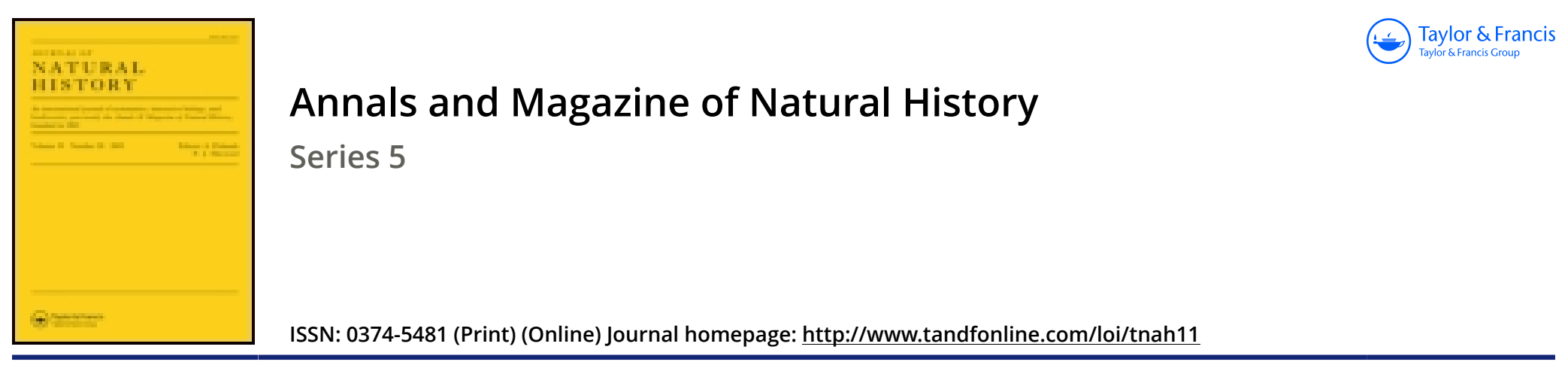

\title{
XXXVII.—On the Oæcium of Spiralaria florea, Busk
}

\section{J.J. Quelch B.Sc.}

To cite this article: J.J. Quelch B.Sc. (1883) XXXVII.—On the Oæcium of Spiralaria florea, Busk, Annals and Magazine of Natural History, 11:64, 276-277, DOI: 10.1080/00222938309459144

To link to this article: http://dx.doi.org/10.1080/00222938309459144

$$
\text { 曲 Published online: } 07 \text { Oct } 2009 .
$$

Submit your article to this journal $\pi$

Џ Article views: 4

Q View related articles $\asymp$ 
they undergo by their transfer to the object-slide. Generally we see only slow alterations in the hyaline mass; but once I succeeded in observing true pseudopodia (fig. 5). These were obtuse processes, one of which was forked at the end. Their movements were very slow. Such a specimen had thus some resemblance to a monothalamian Rhizopod. Nothing is to be seen in the living animal of a nucleus or a contractile vacuole. The latter is probably not present at all, as $A m e e b a$ obtecta is a marine form; the nucleus, however, may be rendered very distinctly visible by means of reagents.

If the $A m o b a$ be treated in the fashion described at the beginning, and then stained with picrocarmine, the intensely reddened nucleus makes its appearance distinctly, even in a short time. It is seen sometimes at the posterior end of the body, sometimes in the middle, and it always appears as a uniformly red-coloured mass. The vacuoles in the protoplasm are also very well preserved under this mode of treatment.

As to the mode of reproduction of this $A$ moeba I possess no observations. It certainly takes place by binary division; and the portion issuing from the shell will probably at once form a new envelope for itself. This seems to be shown by the circumstance that we very often find pairs of Amobe which lie with their carapaces quite close together.

These Rhizopods have evidently no tendency to undertake migrations, and hence, when the conditions are favourable, lie together in great quantities, and thus form regular societies.

[To be continued.]

XXXVII.-On the Oocium of Spiralaria florea, Busk. By J. J. QueLch, B.Sc. (Lond.), Assistant, Zoological Department, British Museum.

THE genus Spiralaria was established by Prof. Busk for the reception of the beantiful and curious Australian Polyzoon which he described and figured under the name Spiralaria florea in the 'Quarterly Journal of Microscopic Science,' new series, vol. i. (1861) p. 153. The same species has since been redescribed and figured by Prof. $\mathrm{M}^{\prime} \mathrm{Coy}$ in the 'Prodromus of the Zoology of Victoria,' decade v. (1880) p. 31; and supplementary information is given as to the nature of the mouth of the cell, of the avjcularia, of the margin of the cell, and of the lamina on which the cells are placed; but no mention is made by this latter observer of the occurrence of ocecia. These were absent from the specimen which was described by Prof. Busk; and as I can find no record of them 
by any later writer, it seems desirable to notify their presence on specimens in the British-Museum collection.

These specimens were presented to the British Museum by the Liverpool Free Museum in May 1867, and were obtained from South Australia.

The ocecia are semicircular or somewhat subglobose, slightly everted at the margin, covered by the avicularia, into the cavity of which they project, and continuous with these at their basal portion, which, being attached along the whole width of the cells, thus presents a very wide mouth. In all the preparations made, they occur only on those marginal cells on which the very large avicularia are placed; and owing to the superposition of these, the nature of the surface is rendered somewhat difficult to determine with certainty. It seems, however, to be smooth or slightly granulated. A reference to the figure given by Prof. Busk will help to give an exact comprehension of the relative positions of the oceia and avicularia ; it is only needed to increase the size of the marginal avicularia there given, especially the width of the basal part, and to add subglobose ooecia arising within them and continuous with them at the base.

A peculiar and interesting character of the cells, and one that is represented in the figure given by Prof. $\mathbf{M}^{\prime} \mathrm{Coy}$, is the presence, along each side of the wall, of a "row of minute aculeate spines or denticles" placed opposite each other at short intervals. Seen under a high power of the microscope these are not simply spines, but hooks with the curved portion turned downwards.

It seems worth while to remark that in the figures given both by Prof. Busk and Prof. $\mathrm{M}^{\prime}$ Coy the whole drawing has been reversed (apparently not having been reversed on the stone), so that both the suberect blunt spine which occurs on the upper left margin of the cells (left to an observer lying as it were in the cell, and looking through the mouth) and the mandibles of the avicularia, which, as Prof. $\mathbf{M}^{\circ}$ Coy observes, all open towards the same direction (that is, towards the left side of the cell and the proximal portion of the zoarium), have become placed on the right.

XXXVIII.-On a small Series of Lepidoptera from Corea. By Arthur G. Butler, F.L.S., F.Z.S., \&c.

A SMALL packet of Lepidoptera has just been received from Lieut. Alfred Carpenter, of H.M.S. 'Magpie,' of which, as it 